\title{
The Effect of Setting Reading Goals on the Vocabulary Retention of Iranian EFL Learners
}

\author{
Akbar Hesabi \\ English Department, Faculty of foreign Languages, University of Isfahan, Isfahan, Iran \\ Email: a.hesabi11@yahoo.com \\ Saeed Ketabi \\ English Department, Faculty of foreign Languages, University of Isfahan, Isfahan, Iran \\ Email: S.ketabi@yahoo.com \\ Abbas Eslami Rasekh \\ English Department, Faculty of foreign Languages, University of Isfahan, Isfahan, Iran \\ Shahnaz Kazemi \\ English Department, Islamic Azad Najafabad University, Najafabad, Iran
}

\begin{abstract}
This study investigates the effects of setting reading goals on the vocabulary retention of Iranian EFL readers. The aim is to find out which type of goals can be more influential on vocabulary retention. The population includes 120 students, 16 to 18 years old, and all female at Iranian junior high schools. Out of them 60 homogenized students were selected through administering one Nelson Proficiency Test (2001). They were divided to four groups of $\mathbf{1 5}$ students, three groups with different reading goals and a control group. After the treatment, a vocabulary post test was administered for all groups after two weeks. Then an ANOVA used to analyze the results of the tests. The results revealed that there was a significant difference between the groups with different goals and the control group. The findings suggested that setting reading goals has a positive effect on vocabulary retention of teaching and pleasure groups and negative effect on taking test group.
\end{abstract}

Index Terms—reading goal, reading comprehension, vocabulary learning, retention, L2 text

\section{INTRODUCTION}

Skilled adult readers consider reading goals as an important factor on how to read. Setting reading goals affects the pace of reading and influences on the style of reading as the literature indicates (Pressley, Brown, El-Dinary, \& Afflerbach, 1995; Pressley \& Afflerbach, 1995; Wyatt et al., 1993). A consistent relationship was found between reading goals and reading strategy by Taraban, Rynearson and Kerr (2000). Successfully learning from text depends heavily on reading goals, but no researches have been found worked on whether providing a learner with a specific reading goal will improve learning from text. The purpose of this study is to determine if giving learners explicit reading goals, can improve their learning. Although goal orientation as a motivational characteristic of the learner has been addressed in previous studies, none have considered the effect of setting reading goals on the vocabulary retention.

This research focuses on the following research hypotheses:

1- Setting a reading goal before reading has no effect on the vocabulary retention of EFL high school students.

2. Setting different reading goals has no effect on the vocabulary retention of EFL high school students.

In this study three reading goals have be considered: reading for pleasure, reading for taking test, and reading for teaching other students.

\section{METHOD}

\section{A. Participants}

To select the participants of the study, a group of 120 students were selected randomly from among the third grade students in a high school in Iran, Najaf-Abad city. Subsequently, a proficiency test was administered to all the participants to make four homogeneous groups in terms of their proficiency level. After scoring the test, 60 students whose score range fell between one standard deviation (SD) above and below the mean were selected to participate in the study. These participants were divided into four homogeneous groups, each consisted of 15 students, based on their proficiency level. They included a control group and three experimental groups.

\section{B. Materials}

Through the various phases of the study, the following materials were used. 


\section{Nelson Proficiency Test}

In order to find out the general English proficiency level of the subjects of the study a Nelson proficiency test(2001) was selected (from the lower intermediate section of the Practice test II) and was administered on the whole population to choose the control and experimental groups.

\section{Vocabulary pre-test}

In order to study the amount of vocabulary retention among the third grade students of high school studying English as a foreign language, the control and experimental groups were supposed to read three short stories each containing 15 unfamiliar words in three different sessions. To find out whether the participants in control and experimental groups were familiar with these words, the list of the new words found in the short stories, consisting of 50 items was given to them and they were asked to write the L1 meaning of the words. Most of the words were unfamiliar to the students. Those vocabulary items which were familiar for the participants ( 5 items) were deleted and those which were unknown to the participants were identified to be considered in the study.

\section{Short stories}

Three short stories suitable for lower intermediate students containing the unfamiliar words were selected and their readability was computed which was reasonable.

\section{Vocabulary Tests}

During the treatment phase of the study, after each session of reading a short story, a vocabulary test was run. The tests were constructed by the researchers and piloted on other students at the same level of knowledge. The reliability of these tests was calculated through KR-21 and they were $0.75,0.84$, and 0.70 . The validity of the tests was confirmed by two experts in the field.

\section{Vocabulary post-test}

At the end of the treatment phase (after a two weeks interval), a post-test was administered to students of the experimental and control groups in which they were asked to write the meaning of those vocabulary items which were already unfamiliar with, to evaluate the amount of the retention of the new words.

\section{Procedure}

Following the proficiency test (Nelson test II , 2001), four homogeneous groups were identified to participate in the study.

\section{Pilot study}

The prepared vocabulary tests were piloted to another group of third grade students in high school similar in English proficiency level to the experimental and control groups. The reliability of these tests was calculated through KR-21. Two experts in the fields confirmed the validity of the tests.

\section{Vocabulary pre-test}

In this phase of the study, a list of 50 new vocabulary items found in the short stories which were considered to be used in the treatment part of the study was selected and given to participants in four groups. Regarding the knowledge level of students who were studying in third grade of high school and considering the vocabulary items which were covered in their textbooks so far, the items which seemed to be unfamiliar to the participants were selected and they were asked to write their meaning in their native language (Persian). After the process of item analysis, 5 vocabulary items which were familiar to the participants were deleted and 45 words were considered in the next phase of the study.

\section{Treatment}

In this phase of the study, the experimental and the control groups were given three short stories, each story in one session, and they were asked to read each short story with special goal like pleasure, taking test, and teaching other students except the control group with no pre-set goal. The students' questions in understanding short stories were answered. They read the texts during a period of 15 minutes of the class time. After reading, each group was required to do a specific activity. One group was required to take a test, the other group was asked to teach to the other students and the pleasure group was required to tell the gist of the story. Then all the groups were asked to answer ten multiple choice questions related to the short stories without informing them before. The reliability of these tests was calculated through KR-21 and they were $0.75,0.84$, and 0.70 . The validity of the tests was confirmed by two experts.

\section{Vocabulary post-test}

In order to measure the amount of the vocabulary retention by the experimental groups and to compare it with the control group, a vocabulary post-test was administered to four groups, similar in form to the pre-test, in which they were asked to write the meaning of 45 vocabulary items in their L1 for thirty minutes, two weeks later. It included the same words in the pretest and the new words in the short stories. The post-test was administered without informing the participants in advance.

\section{Scoring of the Tests and Data Analysis}

The pre-test contained 50 vocabulary items and students were supposed to write their L1 meanings based on the instruction. The post-test contained 45 vocabulary items with the same instruction. In order to score these tests, one mark was considered for each correct L1 meaning and no mark for those vocabulary items which were left blank or answered wrongly by the participants. 


\section{E. Data Analyses}

After the collection of the required data, the scores of the participants on all tests were processed using the statistical package for the social sciences (SPSS, version 9). Specifically, the following analyses were conducted: descriptive statistics, ANOVA and post hoc test. The obtained data of the study will be displayed in the following tables.

TABLE 1.

DESCRIPTIVE STATISTICS OF THE THREE TREATMENTS

\begin{tabular}{|c|c|c|c|c|c|c|c|c|}
\hline & & & \multirow[t]{2}{*}{$\mathrm{N}$} & \multirow[t]{2}{*}{ Mean } & \multirow[t]{2}{*}{ Std. Deviation } & \multirow[t]{2}{*}{ Std. Error } & \multicolumn{2}{|c|}{ 95\% Confidence Interval for Mean } \\
\hline & & & & & & & Lower Bound & Upper Bound \\
\hline treatment1 & $\begin{array}{l}\text { teaching_group } \\
\text { taking_test } \\
\text { pleasure_reading } \\
\text { control_group } \\
\text { Total } \\
\text { Model }\end{array}$ & $\begin{array}{l}\text { Fixed } \\
\text { Effects } \\
\text { Random } \\
\text { Effects }\end{array}$ & $\begin{array}{l}15 \\
15 \\
15 \\
15 \\
60\end{array}$ & $\begin{array}{l}18.4000 \\
15.8667 \\
17.8000 \\
17.2000 \\
17.3167\end{array}$ & $\begin{array}{l}1.29835 \\
1.84649 \\
1.42428 \\
2.17781 \\
1.92655 \\
1.72240\end{array}$ & $\begin{array}{l}.33523 \\
.47676 \\
.36775 \\
.56231 \\
.24872 \\
.22236 \\
.54186\end{array}$ & $\begin{array}{l}17.6810 \\
14.8441 \\
17.0113 \\
15.9940 \\
16.8190 \\
16.8712 \\
15.5922\end{array}$ & $\begin{array}{l}19.1190 \\
16.8892 \\
18.5887 \\
18.4060 \\
17.8143 \\
17.7621 \\
19.0411\end{array}$ \\
\hline treatment 2 & $\begin{array}{l}\text { teaching_group } \\
\text { taking_test } \\
\text { pleasure_reading } \\
\text { control_group } \\
\text { Total } \\
\text { Model }\end{array}$ & $\begin{array}{l}\text { Fixed } \\
\text { Effects } \\
\text { Random } \\
\text { Effects }\end{array}$ & $\begin{array}{l}15 \\
15 \\
15 \\
15 \\
60\end{array}$ & $\begin{array}{l}18.9333 \\
16.2000 \\
17.6667 \\
16.6667 \\
17.3667\end{array}$ & $\begin{array}{l}1.03280 \\
1.74028 \\
1.67616 \\
1.83874 \\
1.88632 \\
1.60357\end{array}$ & $\begin{array}{l}.26667 \\
.44934 \\
.43278 \\
.47476 \\
.24352 \\
.20702 \\
.60522\end{array}$ & $\begin{array}{l}18.3614 \\
15.2363 \\
16.7384 \\
15.6484 \\
16.8794 \\
16.9520 \\
15.4406\end{array}$ & $\begin{array}{l}19.5053 \\
17.1637 \\
18.5949 \\
17.6849 \\
17.8540 \\
17.7814 \\
19.2928\end{array}$ \\
\hline treatment3 & $\begin{array}{l}\text { teaching_group } \\
\text { taking_test } \\
\text { pleasure_reading } \\
\text { control_group } \\
\text { Total } \\
\text { Model }\end{array}$ & $\begin{array}{l}\text { Fixed } \\
\text { Effects } \\
\text { Random } \\
\text { Effects }\end{array}$ & $\begin{array}{l}15 \\
15 \\
15 \\
15 \\
60\end{array}$ & $\begin{array}{l}18.9333 \\
16.4667 \\
17.8000 \\
15.1333 \\
17.0833\end{array}$ & $\begin{array}{l}.88372 \\
1.92230 \\
1.42428 \\
1.92230 \\
2.11766 \\
1.59687\end{array}$ & $\begin{array}{l}.22817 \\
.49634 \\
.36775 \\
.49634 \\
.27339 \\
.20616 \\
.82254\end{array}$ & $\begin{array}{l}18.4439 \\
15.4021 \\
17.0113 \\
14.0688 \\
16.5363 \\
16.6704 \\
14.4656\end{array}$ & $\begin{array}{l}19.4227 \\
17.5312 \\
18.5887 \\
16.1979 \\
17.6304 \\
17.4963 \\
19.7010\end{array}$ \\
\hline post_test & $\begin{array}{l}\text { teaching_group } \\
\text { taking_test } \\
\text { pleasure_reading } \\
\text { control_group } \\
\text { Total } \\
\text { Model }\end{array}$ & $\begin{array}{l}\text { Fixed } \\
\text { Effects } \\
\text { Random } \\
\text { Effects }\end{array}$ & $\begin{array}{l}15 \\
15 \\
15 \\
15 \\
60\end{array}$ & $\begin{array}{l}18.1333 \\
12.6000 \\
17.1333 \\
13.2000 \\
15.2667\end{array}$ & $\begin{array}{l}1.55226 \\
2.29285 \\
1.55226 \\
3.48876 \\
3.33887 \\
2.35837\end{array}$ & $\begin{array}{l}.40079 \\
.59201 \\
.40079 \\
.90079 \\
.43105 \\
.30446 \\
1.38698\end{array}$ & $\begin{array}{l}17.2737 \\
11.3303 \\
16.2737 \\
11.2680 \\
14.4041 \\
14.6568 \\
10.8527\end{array}$ & $\begin{array}{l}18.9929 \\
13.8697 \\
17.9929 \\
15.1320 \\
16.1292 \\
15.8766 \\
19.6806\end{array}$ \\
\hline
\end{tabular}

Considering the mean scores of four groups in each treatment (table 1), the teaching group gained the highest means. It is considerable that the mean of taking test group is lower than control group in treatment 1, 2 and in delayed post-test.

ABLE 2.

ANOVA

\begin{tabular}{|l|l|l|l|l|l|l|}
\hline & & Sum of Squares & df & Mean Square & F & Sig. \\
\hline treatment1 & Between Groups & 52.850 & 3 & 17.617 & 5.938 & .001 \\
\hline & Within Groups & 166.133 & 56 & 2.967 & & \\
\hline & Total & 218.983 & 59 & & & \\
\hline treatment2 & Between Groups & 65.933 & 3 & 21.978 & 8.547 & .000 \\
\hline & Within Groups & 144.000 & 56 & 2.571 & & \\
\hline & Total & 209.933 & 59 & & & \\
\hline treatment3 & Between Groups & 121.783 & 3 & 40.594 & 15.919 & .000 \\
\hline & Within Groups & 142.800 & 56 & 2.550 & & \\
\hline & Total & 264.583 & 59 & & & \\
\hline post_test & Between Groups & 346.267 & 3 & 115.422 & 20.752 & .000 \\
\hline & Within Groups & 311.467 & 56 & 5.562 & & \\
\hline & Total & 657.733 & 59 & & & \\
\hline
\end{tabular}

Table 2 shows that since the statistics referring to significant difference between the groups is smaller than 0.05 in all treatments, there is a significant difference in the performance of the four groups on vocabulary retention. Therefore the 
first hypothesis of the research (Setting a reading goal before reading has no effect on the vocabulary retention of EFL high school students) is rejected. This implies the fact that setting different reading goals affects the subjects' retention ability.

1. Post Hoc test

TABLE 3.

MULTIPLE COMPARISONS OF THE LEARNERS' MEANS WITH DIFFERENT READING GOALS Scheffe

\begin{tabular}{|c|c|c|c|c|c|c|}
\hline \multirow[b]{2}{*}{ (I) group } & \multirow[b]{2}{*}{ (J) group } & \multirow{2}{*}{$\begin{array}{c}\text { Mean } \\
\text { Difference } \\
(\mathrm{I}-\mathrm{J}) \\
\end{array}$} & \multirow[b]{2}{*}{ Std. Error } & \multirow[b]{2}{*}{ Sig. } & \multicolumn{2}{|c|}{ 95\% Confidence Interval } \\
\hline & & & & & Lower Bound & Upper Bound \\
\hline \multirow[t]{3}{*}{ teaching group } & test group & $3.32^{*}$ & .429 & .000 & 2.08 & 4.55 \\
\hline & pleasure group & 1.00 & .429 & .155 & -.24 & 2.24 \\
\hline & control group & $3.05^{*}$ & .429 & .000 & 1.81 & 4.29 \\
\hline \multirow[t]{3}{*}{ test group } & teaching group & $-3.32^{*}$ & .429 & .000 & -4.55 & -2.08 \\
\hline & pleasure group & $-2.32^{*}$ & .429 & .000 & -3.55 & -1.08 \\
\hline & control group & -.27 & .429 & .943 & -1.50 & .97 \\
\hline \multirow[t]{3}{*}{ pleasure group } & teaching group & -1.00 & .429 & .155 & -2.24 & .24 \\
\hline & test group & $2.32^{*}$ & .429 & .000 & 1.08 & 3.55 \\
\hline & control group & $2.05^{\star}$ & .429 & .000 & .81 & 3.29 \\
\hline \multirow[t]{3}{*}{ control group } & teaching group & $-3.05^{\star}$ & .429 & .000 & -4.29 & -1.81 \\
\hline & test group & .27 & .429 & .943 & -.97 & 1.50 \\
\hline & pleasure group & $-2.05^{\star}$ & .429 & .000 & -3.29 & -.81 \\
\hline
\end{tabular}

Based on observed means.

*. The mean difference is significant at the .05 level.

The second hypothesis was concerned with the question of whether there is any relationship between the different reading goals and EFL learners' retention. Considering table 3 and by comparing the control group and the other groups, the mean difference of control and teaching group is 3.05 and this is significant (0.00 is smaller than 0.05$)$. This shows that there is a significant difference between the means of the group with teaching goal and the control group.

The mean difference of control and pleasure groups is -2.05 and it is significant $(0.00<0.05)$. But the mean difference of control and test group is 0.27 and it is not significance $(0.943>.05)$. This shows that there is not a significant difference between the means of the test group and the control group. These results indicate that setting different goals have different effects on the means of each group. Although, teaching and pleasure goals have significant positive effects on the means of the students, testing goal has no significant effect on mean (even based on the descriptive statistics of table 1 the means of the test groups in treatments and post test are lower than the control and of course other groups). Therefore, the mean difference between groups shows that the mean of control group is lower than teaching and pleasure groups and the means of control and testing groups has no significant difference.

\section{DISCUSSION, CONCLUSION, AND IMPLICATION}

The post-test results of the teaching and pleasure groups, as indicated by the descriptive statistics were higher than the results obtained by the control group. Therefore, it can be claimed that the subjects who participated in the reading activity with setting reading goals (for teaching and pleasure) seemed to have learned the meaning of more words than those in the control group. The results of the study indicate the importance of setting reading goals before reading. As Rivers (1981) notes, vocabulary cannot be taught although it can be explained, presented, demonstrated along with other techniques and activities, and must be learned by individuals.

As stated before, this study investigated two hypotheses: 1. Setting a reading goal before reading has no effect on the vocabulary retention of EFL high school students. The findings of this study rejected this hypothesis. In other words, by comparing the results obtained by experimental groups, it is clear that there are significant differences between the retention of these groups and the control group. It shows that setting reading goal before reading has a significant effect on vocabulary retention of students; of course, positive effect for those with teaching and pleasure reading goals and negative effect for those with taking test goal. The results show that taking test goal not only does not increase the students capacity to recall the words better but also decrease the level of their performance. It can be because of the students' stress of taking test.

The second hypothesis stated: Setting different reading goals has no effect on the vocabulary retention of EFL high school students. Referring back to table 3 and considering the results of descriptive statistics and one way ANOVA of the post-test in table 2 this hypothesis is rejected. The amount of retention of vocabulary in the participants possessing teaching goals and pleasure goals is higher than control group. Unlike teaching group and pleasure group there is a lower retention of vocabulary in taking test group comparing with control group. 
There were some limitations in this study. The first problem dealt with the reluctance of a few less-enthusiastic and less-motivated students to participate in the study, i.e. to read short stories for taking test, teaching the other students and for pleasure. The reason behind this unwillingness may be due to the current situation of educational evaluation in Iran. Students have gradually been accustomed to the procedure of "read for score" and in most cases, the only criteria for passing the course, here in Iran, are the score, which is often obtained from the written examinations regardless of other capabilities of the learners.

These findings have clear implications for the future studies.

1- The participants of this study were the third graders in high school in Iran. This study can be replicated with TEFL students at the university and the results can be compared with this study and other studies.

2- In this study, one-word units were mostly tested. Similar research with multi-word units also needs to be done.

3 - The number of vocabulary considered in this study was 45 words. This study may be replicated with either fewer or more words at different levels and the results can be compared.

4- In this study, "vocabulary retention" in the experimental and control groups was studied by only one post-test. More retention tests with different elapse of finite times can be addressed in future studies and the retention of vocabulary can be compared to see whether the results are stable or not.

\section{REFERENCES}

[1] Nelson, T. (2001). Practice test II. Hong Kong: Bright Sun Printing Press.

[2] Pressley, M., \& Afflerbach, P. (1995). Verbal protocols of reading: The nature of constructively responsive reading. Hillsdale, NJ: Erlbaum

[3] Pressley, M., Brown, R., El-Dinary, P.B., \& Afflerbach, P. (1995). The comprehension instruction that students need: Instruction fostering constructively responsive reading. Learning Disabilities Research and Practice, 10, 215-224.

[4] Rivers, W.M. (1981).Teaching foreign language skills. Chicago: The university of Chicago press.

[5] Taraban, R., Rynearson, K., \& Kerr, M. (2000). College students' academic performance and self-reports of comprehension strategy use. Reading Psychology,21, 283-308. Thompson, B., \& Danie.

[6] Wyatt, D., Pressley, M., El-Dinary, P., Stein, S., Evans, p., \& Brown, R. (1993). Comprehension strategies, worth and credibility monitoring, and evaluations: Cold and hot cognition when experts read professional articles that are important to them. Learning and Individual Differences, 5, 49-72.

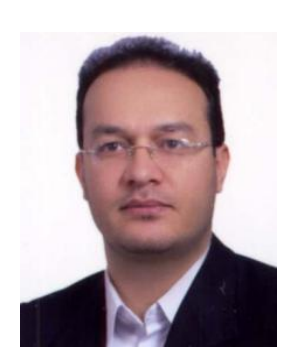

Akbar Hesabi received his $\mathrm{PhD}$ degree in theoretical Linguistics in 2009 from Allameh Tabatabai University, Tehran, Iran. He is currently teaching linguistic and translation courses at the University of Isfahan. His current research interests include psycholinguistics, neurolinguistics and Translation. He has published several articles and a book.

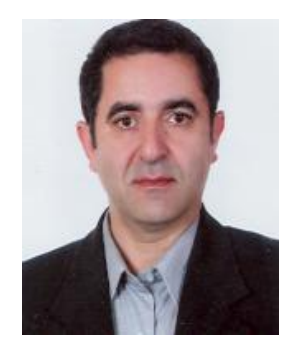

Saeed Ketabi has a PhD in Applied Linguistics from the University of Cambridge, England and is currently teaching ELT courses at the University of Isfahan. He has published and presented several papers.

Abbas Eslami Rasekh (MA, PhD Monash) is an Assistant Professor at Isfahan University in Iran. His research interests and publications are issues related to EAP/ESP, Discourse Analysis, pragmatics, sociolinguistics, translation studies, issues related to relativity across cultures, and teacher education.

Shahnaz Kazemi received her MA degree in TEFL from Najafabad University, Najafabad, Iran. 